\title{
Prevention of UVl Precipitation in Alkaline Aqueous Solutions by the Siderophore Desferrioxamine B
}

Matthew Edward Kirby ${ }^{1}$, Jason Louis Sonnenberg ${ }^{2}$, Jonathan Watson ${ }^{1}$, Dominik Jakob Weiss ${ }^{* 1,3}$

\author{
${ }^{1}$ Earth Science and Engineering, Imperial College London, United Kingdom \\ ${ }^{2}$ Gaussian Inc., Wallingford, Connecticut 06492, United States \\ ${ }^{3}$ Geological and Environmental Sciences, Stanford University, United States
}

Corresponding author: $\underline{\text { matt } 110 @ \text { hotmail.co.uk, d.weiss@imperial.ac.uk }}$ 


\section{Abstract}

In alkaline and saline solutions, uranium VI (UVI) forms uranyl salts, limiting its mobility in leachates released from nuclear waste repositories into groundwater. However, recent experimental and computational work suggested that natural organic molecules widely present in groundwater such as siderophores could potentially prevent solid precipitation because of the formation of stable UVIsiderophore complexes. It is important we assess the impact of siderophores on aqueous $U^{\mathrm{VI}}$ chemistry as they could mobilise $U^{\mathrm{V}}$ from contaminated land and radioactive waste storage and disposal sites. Here we test this hypothesis by combining for the first time experimental studies on uranium precipitation in alkaline $\mathrm{pH}$ in the presence of desferrioxamine $\mathrm{B}$ (DFOB) and electron structure method calculation of uranyl - hydroxamate complexes to assess their stability. Stirred batch experiments containing 0 to $420 \mu \mathrm{M}$ DFOB, $42 \mu \mathrm{M} \mathrm{U}^{\mathrm{VI}}$ and $0.1 \mathrm{M} \mathrm{NaCl}$ were conducted at $\mathrm{pH}$ 11.5. DFT was employed to explore the relative stability of different $\mathrm{U}^{\mathrm{V}}$-hydroxamate complexes, representative of the local binding mode of DFOB. During the stirred batch experiments, $5 \%, 11$ $12 \%, 41-53 \%, 95-96 \%$ and $100 \%$ of $U^{v l}$ passes through the filter membranes $(0.2-1 \mu \mathrm{m}$ pore diameter) after 24 hours when 0, 4.2, 42, 130 and $420 \mu \mathrm{M}$ DFOB was added to solution. The DFT results suggest one hydroxamate functional group is most likely to complex with $U^{\mathrm{VI}}$ with $\Delta_{\mathrm{r}} \mathrm{G}$ calculated as $+3 \mathrm{~kJ} / \mathrm{mol}$ and $-9 \mathrm{~kJ} / \mathrm{mol}$ for $\left[\mathrm{UO}_{2}(\mathrm{OH})_{3}\left(\mathrm{Lmono}_{\mathrm{mo}}\right]^{2-}\right.$ and $\left[\mathrm{UO}_{2}(\mathrm{OH})_{2}(\mathrm{~L})\right]^{-}$respectively. Conversion of the experimentally derived $\log \beta(-1.2 \pm 0.3)$ through the equation $\Delta_{r} G=-2.303 R T \log \beta$ provides $\Delta_{\mathrm{r}} \mathrm{G}$ of $+7 \mathrm{~kJ} / \mathrm{mol}$, similar to the $\Delta_{\mathrm{r}} \mathrm{G}$ of these two complexes. The results of our study confirm that $U^{V I}$ precipitation could be hindered by the formation of a DFOB complex with $U^{V I}$ complexation through a single hydroxamate functional group as a likely mechanism. These results highlight the mobilising effect siderophores have on $U^{\mathrm{VI}}$ from contaminant sources and need to be incorporated in environmental risk assessment studies. 


\section{Introduction}

Uranium $(U)$ is a toxic element that can threaten groundwater quality if mobilised from a solid-phase source. Uranium is present in alkaline $(\mathrm{pH}>9)$ solutions in a variety of scenarios. Surface, near surface, and deep geological disposal facilities for radioactive waste often grout the waste and use cement to backfill the facility. ${ }^{1-3}$ Groundwater leaching of the grout waste form and cement backfill will lead to alkaline $(\mathrm{pH} 9-14)$ and saline solutions $(\mathrm{I}>0.1 \mathrm{M}) .{ }^{4,5}$ Radioactive waste is also stored in high $\mathrm{pH}$ conditions free of cement and grout. For example, at Hanford in the USA, high level liquid radioactive waste is collected from reprocessing Pu for nuclear weapons. These tanks contain 5.2 to $13.4 \mathrm{M} \mathrm{Na}$ and $31 \mathrm{mg} / \mathrm{L} \mathrm{U}$ in $\mathrm{pH} 13$ solutions. $^{6-8}$ At Sellafield in the UK, spent fuel rods are stored in $\mathrm{pH}>10$ solutions adjusted with $\mathrm{NaOH} .{ }^{9}$ Tailings from $\mathrm{U}$ mining can have $\mathrm{pH} 10$ solutions. ${ }^{10}$ Alkaline conditions can also occur in natural systems such as at Maqarin, Jordan $(\mathrm{pH} 12.5)^{11,12}$ and the Allas Springs, Cyprus $(\mathrm{pH} 9.25-11.71){ }^{13}$

In alkaline solutions $U^{\text {VI }}$ precipitates from solution, limiting its mobility. This is a key reason why to store nuclear waste in cement. This has been observed at $\mathrm{pH} \geq 10$ in batch experiments in solutions containing $28.5 \mu \mathrm{M} \mathrm{U} \mathrm{VI}^{\mathrm{V}}$ and $0.01-0.05 \mathrm{M} \mathrm{NaClO}_{4}$. During these batch sorption experiments, the precipitates attach to mineral surfaces, significantly reducing $U^{\mathrm{VI}}$ mobility. ${ }^{8,14,15}$ This was studied in greater detail recently in a series of batch experiments which explored $\mathrm{U}^{\mathrm{Vl}}$ sorption onto quartz, an iron-coated sandstone and a volcanic rock. ${ }^{16}$ The authors found $10 \mathrm{ppm} \mathrm{UVI}$ precipitated from $0.1 \mathrm{M}$ $\mathrm{NaCl}$ solutions and was immobilised on the iron-coated sandstone and volcanic rock between $\mathrm{pH} 10$ and 12. $U^{\mathrm{VI}}$ was not immobilised chemically on quartz sand, but physically in quartz sand columns under the same chemical conditions. ${ }^{17}$

The above studies suggest that $U^{V I}$ mobility is limited under alkaline and saline conditions. However, these studies were conducted in inorganic systems, while in the natural environment organic molecules will be prevalent. These organic molecules could potentially form aqueous complexes with $U^{V I}$, limiting precipitation. If these complexes form, then uranium mobility from contaminated 
land and radioactive waste storage and disposal facilities could be greatly enhanced. One such class of organic molecules are siderophores. These are multidentate organic molecules released by plants, fungi and bacteria in alkaline, oxygenated conditions to solubilise iron. ${ }^{18}$ Concentrations of these molecules vary with depth in the geosphere, varying from $<10 \mu \mathrm{M}$ in rocks up to several $\mathrm{mM}$ in the rhizosphere. ${ }^{19-22}$

Desferrioxamine B (DFOB) is a (tris)hydroxamate siderophore widely present in groundwater (Figure 1). ${ }^{23}$ DFOB enhances the solubility of $U^{\mathrm{IV}}$ minerals between $\mathrm{pH} 3-8$ under reducing conditions, ${ }^{24}$ and complexes with $\mathrm{U}^{\mathrm{VI}}$ between $\mathrm{pH} 4-10$ with stability constant $(\log \beta)$ between 17.12 to $22.93 .{ }^{25,26}$ However, to the best of our knowledge, $\mathrm{U}^{\mathrm{V}}$ interactions with DFOB has not been explored above $\mathrm{pH}$ 10 , the very region where $U$ precipitation happens. It has been shown that multi-dentate organic molecules produced from cellulose degradation ( $\alpha$-isosaccharinic) and cement degradation (Dgluconate) inhibit the precipitation of $\mathrm{U}^{\mathrm{IV}}$ at $\mathrm{pH} 13.5^{27,28}$ and $\mathrm{U}^{\mathrm{VI}}$ at $\mathrm{pH} 12-13 .{ }^{29-31}$ However, these ligands contain the carboxylate functional group rather than the functional group found in DFOB. A key process which could be responsible for reduced uranium precipitation is the formation of aqueous complexes. One way in which we can explore this is through Density Functional Theory (DFT). This computational chemistry approach can be used to calculate the Gibbs free energy of a reaction $\left(\Delta_{r} G\right)$ and subsequently the $\log \beta$. The advantages of this approach is that it can be used to calculate stability constants in alkaline conditions where alkaline errors in glass electrodes, and uranium precipitation hinder their experimental determination. ${ }^{29,32}$ 
<smiles>CC(=O)N([O-])CCCCCNC(=O)CCC(=O)N([O-])CCCCCNC(=O)CCC(=O)N([O-])CCCCCN</smiles>

Figure 1. Desferrioxamine B is presented (a) along with its key reactive functional group, hydroxamate (b).

The aim of this study was to determine whether siderophores typically found in groundwater and represented as desferrioxamine $B$ prevents $U^{V /}$ precipitation in alkaline solutions by forming an aqueous complex with $\mathrm{U}^{\mathrm{VI}}$, and to investigate if the formation of an aqueous $\mathrm{U}^{\mathrm{VI}}-\mathrm{DFOB}$ complex is the reason (in contrast to adsorption on surface). A multi-disciplinary approach which combines batch experiments with Density Functional Theory (DFT) has been employed. Stirred batch experiments were conducted with 0 to $420 \mu \mathrm{M}$ DFOB in solutions containing $42 \mu \mathrm{M} \mathrm{U}^{\mathrm{VI}}$ and $0.1 \mathrm{M} \mathrm{NaCl}$ at pH 11.5. Samples were filtered through 0.2 to $1 \mu \mathrm{m}$ filter membranes over three days (short term) or two months (long term). DFT was used to investigate whether the functional groups of DFOB could complex with $\mathrm{U}^{\mathrm{v}}$.

\section{Methods}

\subsection{Chemicals}

All chemicals were analytical grade and all solutions were prepared with $15 \mathrm{M} \Omega . c m$ de-ionised water (Merck Millipore). $\mathrm{NaOH}$ pellets (VWR) and distilled $6 \mathrm{M} \mathrm{HCl}$ were used to prepare $1 \mathrm{M} \mathrm{NaOH}$ and $\mathrm{HCl}$ solutions for $\mathrm{pH}$ adjustment. $\mathrm{NaCl}(\mathrm{VWR})$ was used to control ionic strength. A $1000 \mathrm{mg} / \mathrm{L} \mathrm{U}$ PerkinElmer Pure Plus standard solution was used to prepare all $\mathrm{U}^{\mathrm{Vl}}$ solutions, and Induced Coupled Plasma Mass Spectrometry (ICP-MS) standards. Desferrioxamine mesylate salt powder ( $\geq 92.5 \%)$ 
from Sigma-Aldrich was used as is.

\subsection{Experimental}

Stirred batch reactor experiments were conducted for up to three days to test the short-term effect of DFOB on $U^{V l}$ particle formation. All batch experiments were repeated at least twice. The experiments were conducted in $250 \mathrm{ml}$ amber bottles to prevent photo-oxidation of DFOB. Solutions with a volume of $250 \mathrm{ml}$ containing $0.1 \mathrm{M} \mathrm{NaCl}$ and various DFOB concentrations $(4.2,42,130$ and $420 \mu \mathrm{M}$ ) were created. An approximately $180 \mathrm{ml}$ solution containing the $\mathrm{NaCl}$ and DFOB was initially created and adjusted to the appropriate $\mathrm{pH} 11.5$ so that a $5 \mathrm{ml}$ representative blank could be collected. The DFOB was added in a powder form to create the 130 and $420 \mu \mathrm{M}$ DFOB solutions. A 4.2 mM DFOB stock solution was created and diluted to produce the 4.2 and $42 \mu \mathrm{M}$ DFOB solutions. The 4.2 mM DFOB stock solution was freshly prepared before each experiment to minimise ligand degradation. The DFOB was added and collected as part of the representative blank. $42 \mu \mathrm{M} \mathrm{U}^{\mathrm{VI}}$ was then added to the solution by diluting the $4.2 \mathrm{mM} \mathrm{U}^{\mathrm{VI}}$ standard solution. The $\mathrm{pH}$ was re-adjusted to 11.5 and volume increased to $195 \mathrm{ml}$. The $\mathrm{pH}$ was periodically measured and adjusted throughout the experiment with $1 \mathrm{M} \mathrm{NaOH}$ and $1 \mathrm{M} \mathrm{HCl}$ to maintain the $\mathrm{pH}$ at 11.5. The $\mathrm{pH}$ was measured on collection of a sample and was adjusted if the $\mathrm{pH}$ changed more than $\pm 0.05 \mathrm{pH}$ units of the target value. The $\mathrm{pH}$ was regularly adjusted throughout the experiment. Approximately $5 \mathrm{ml}$ samples were collected and filtered through Whatman nylon membranes $(0.2,0.45$, and $1 \mu \mathrm{m}$ pore diameter), diluted 10 times in $2 \%$ nitric acid and analysed using ICP-MS. During two of the three repeats of the $420 \mu \mathrm{M}$ DFOB experiment, samples were only filtered with a $0.2 \mu \mathrm{m}$ nylon filter membrane.

To test the long term effects of DFOB on $U^{\mathrm{VI}}$ precipitate formation and ligand promoted dissolution/disaggregation, $250 \mathrm{ml}$ solutions containing $42 \mu \mathrm{M} \mathrm{U}^{\mathrm{V}}, 130 \mu \mathrm{M}$ DFOB and $0.1 \mathrm{M} \mathrm{NaCl}$ adjusted to $\mathrm{pH} 11.5$ were placed in a shaking tray for two months $\left(\mathrm{T}=25^{\circ} \mathrm{C}, 130 \mathrm{rpm}\right)$. Three types of experiments were conducted; a control experiment; a precipitation inhibition experiment (see short term batch experiments method); and a dissolution experiment. At the start of the dissolution 
experiment, $42 \mu \mathrm{M} U^{\mathrm{VI}}$ was allowed to precipitate for 48 hours, and then $130 \mu \mathrm{M}$ DFOB was added to solution. $5 \mathrm{ml}$ samples were collected and filtered through $0.2,0.45$ and $1 \mu \mathrm{m}$ Whatman nylon filter membranes, diluted 10 times in 2\% nitric acid and analysed using ICP-MS.

\subsection{Computational}

Electronic structure calculations were carried out with Gaussian 16-Rev. A.03 ${ }^{33}$ using GaussView version $6^{34}$ for pre- and post-processing. All of the structures were geometrically optimized and the frequencies were calculated to confirm local minima. Entropy of the computed structures has been evaluated by employing the gas-phase rigid rotor and harmonic oscillator approximation. No hindered rotation correction was applied. ${ }^{35}$ We employed the DFT model chemistry we have used in previous research. ${ }^{36}$ This used the B3LYP density functional approximation, ${ }^{37-39}$ Dunning's correlationconsistent, polarized valence double zeta basis sets augmented with polarization functions (aug-ccpVDZ ${ }^{40-42}$ were used for ligand atoms and Dolg's MDF60 ${ }^{43}$ relativistic effective core potential were employed for $U^{v l}$. Implicit solvation was accounted for with the integral equation formalism polarizable continuum model (IEFPCM) $\cdot{ }^{44}$ Symmetry was not constrained during the calculations, and all calculations utilized a pruned grid with 99 radial shells and 590 angular points per shell (ultrafine grid). The self-consistent Field (SCF) procedure convergence criteria used during the optimization and frequency calculations were the standard Gaussian values: Maximum force $=4.5 \times 10^{-4}$ Hartrees $/$ Bohr, root mean square (RMS) force $=3 \times 10^{-4}$ Hartrees/Radians, maximum displacement $=1.8 \times 10^{-3} \AA$, RMS displacement $=1.2 \times 10^{-3} \AA$.

\subsection{Reactions employed during the computational}

The reactions presented in Equations 1 to 7 were used to calculate the change Gibbs free energy of reaction $\left(\Delta_{r} G\right)$ for the possible conformers for 1:1 and 1:2 $U^{v 1}$-hydroxamate complexes. In these equations $L$ and $L_{m o n o}$ in the product complex represent bidentate and monodentate binding mode respectively. We selected $\left[\mathrm{UO}_{2}(\mathrm{OH})_{3}\right]^{-}$as the reactant $\mathrm{U}^{\mathrm{Vl}}$ hydroxide species based on speciation modelling which indicated this species accounted for $68 \%$ of $U^{\mathrm{VI}}$ at $\mathrm{pH} 11.5$. A systematic DFT study 
exploring the geometry of mononuclear aqua and hydroxide complexes observed that only one water molecule was complexed directly to $\mathrm{UVI}^{\mathrm{VI}}{ }^{45}$ so we used $\left[\mathrm{UO}_{2}(\mathrm{OH})_{3}\left(\mathrm{H}_{2} \mathrm{O}\right)\right]^{-}$to represent our reactant complex (Figure 4a).

In these equations we add explicit water molecules to better represent the short-range interactions between the reactant and product species and the surrounding water. ${ }^{46,47}$ We have adapted the uranyl structure $\left[\mathrm{UO}_{2}\left(\mathrm{H}_{2} \mathrm{O}\right)_{5}\left(\mathrm{H}_{2} \mathrm{O}\right)_{10}\right]^{2+}$ used by Gutowski and Dixon ${ }^{46}$ which adds an explicit water molecule to each $\mathrm{H}$ atom in the uranyl bound aqua ligands $\left(\mathrm{H}_{2} \mathrm{O}---\left(\mathrm{H}_{2} \mathrm{O}\right)_{2}\right)$. We have extended this to include an explicit water molecule to the $\mathrm{H}$ atom in the uranyl bound hydroxyl groups $\left[\mathrm{OH}---\left(\mathrm{H}_{2} \mathrm{O}\right)\right]^{-}$. This gives $\left[\mathrm{UO}_{2}\left(\mathrm{OH}---\mathrm{H}_{2} \mathrm{O}\right)_{3}\left(\mathrm{H}_{2} \mathrm{O}---\left(\mathrm{H}_{2} \mathrm{O}\right)_{2}\right)\right]$. We have also added an explicit water to each $\mathrm{O}$ atom in the free hydroxyl, $\left[\mathrm{OH}---\mathrm{H}_{2} \mathrm{O}\right]^{-}$and hydroxamate $\left[\mathrm{L}---\left(\mathrm{H}_{2} \mathrm{O}\right)_{2}\right]^{-}$as suggested by previous research. ${ }^{47}$

$$
\begin{aligned}
& {\left[\mathrm{UO}_{2}\left(\mathrm{OH}---\mathrm{H}_{2} \mathrm{O}\right)_{3}\left(\mathrm{H}_{2} \mathrm{O}---\left(\mathrm{H}_{2} \mathrm{O}\right)_{2}\right]^{-}+\left[\mathrm{L}---\left(\mathrm{H}_{2} \mathrm{O}\right)_{2}\right]^{-}=\right.} \\
& {\left[\mathrm{UO}_{2}\left(\mathrm{~L}_{\mathrm{mono}}---\mathrm{H}_{2} \mathrm{O}\right)\left(\mathrm{OH}---\mathrm{H}_{2} \mathrm{O}\right)_{3}\right]^{2-}+4 \mathrm{H}_{2} \mathrm{O}} \\
& {\left[\mathrm{UO}_{2}\left(\mathrm{OH}---\mathrm{H}_{2} \mathrm{O}\right)_{3}\left(\mathrm{H}_{2} \mathrm{O}---\left(\mathrm{H}_{2} \mathrm{O}\right)_{2}\right]^{-}+\left[\mathrm{L}---\left(\mathrm{H}_{2} \mathrm{O}\right)_{2}\right]^{-}=\right.} \\
& {\left[\mathrm{UO}_{2}\left(\mathrm{~L}_{\mathrm{mono}}---\mathrm{H}_{2} \mathrm{O}\right)\left(\mathrm{OH}---\mathrm{H}_{2} \mathrm{O}\right)_{2}\left(\mathrm{H}_{2} \mathrm{O}---\left(\mathrm{H}_{2} \mathrm{O}\right)_{2}\right)\right]^{-}+\left[\mathrm{OH}---\mathrm{H}_{2} \mathrm{O}\right]^{-}+\mathrm{H}_{2} \mathrm{O}} \\
& {\left[\mathrm{UO}_{2}\left(\mathrm{OH}---\mathrm{H}_{2} \mathrm{O}\right)_{3}\left(\mathrm{H}_{2} \mathrm{O}---\left(\mathrm{H}_{2} \mathrm{O}\right)_{2}\right]^{-}+\left[\mathrm{L}---\left(\mathrm{H}_{2} \mathrm{O}\right)_{2}\right]^{-}=\right.} \\
& {\left[\mathrm{UO}_{2}(\mathrm{~L})\left(\mathrm{OH}---\mathrm{H}_{2} \mathrm{O}\right)\left(\mathrm{H}_{2} \mathrm{O}---\left(\mathrm{H}_{2} \mathrm{O}\right)_{2}\right)\right]^{-}+2\left[\mathrm{OH}---\mathrm{H}_{2} \mathrm{O}\right]^{-}+2 \mathrm{H}_{2} \mathrm{O}} \\
& {\left[\mathrm{UO}_{2}\left(\mathrm{OH}---\mathrm{H}_{2} \mathrm{O}\right)_{3}\left(\mathrm{H}_{2} \mathrm{O}---\left(\mathrm{H}_{2} \mathrm{O}\right)_{2}\right]^{-}+\left[\mathrm{L}---\left(\mathrm{H}_{2} \mathrm{O}\right)_{2}\right]^{-}=\right.} \\
& {\left[\mathrm{UO}_{2}(\mathrm{~L})\left(\mathrm{OH}---\mathrm{H}_{2} \mathrm{O}\right)_{2}\right]^{0}+\left[\mathrm{OH}---\mathrm{H}_{2} \mathrm{O}\right]^{-}+5 \mathrm{H}_{2} \mathrm{O}} \\
& {\left[\mathrm{UO}_{2}\left(\mathrm{OH}---\mathrm{H}_{2} \mathrm{O}\right)_{3}\left(\mathrm{H}_{2} \mathrm{O}---\left(\mathrm{H}_{2} \mathrm{O}\right)_{2}\right]^{-}+2\left[\mathrm{~L}---\left(\mathrm{H}_{2} \mathrm{O}\right)_{2}\right]^{-}=\right.} \\
& {\left[\mathrm{UO}_{2}(\mathrm{~L})\left(\mathrm{L}_{\mathrm{mono}}---\mathrm{H}_{2} \mathrm{O}\right)\left(\mathrm{H}_{2} \mathrm{O}---\left(\mathrm{H}_{2} \mathrm{O}\right)_{2}\right)\right]^{0}+3\left[\mathrm{OH}---\mathrm{H}_{2} \mathrm{O}\right]^{-}+3 \mathrm{H}_{2} \mathrm{O}} \\
& {\left[\mathrm{UO}_{2}\left(\mathrm{OH}---\mathrm{H}_{2} \mathrm{O}\right)_{3}\left(\mathrm{H}_{2} \mathrm{O}---\left(\mathrm{H}_{2} \mathrm{O}\right)_{2}\right]^{-}+2\left[\mathrm{~L}---\left(\mathrm{H}_{2} \mathrm{O}\right)_{2}\right]^{-}=\right.} \\
& {\left[\mathrm{UO}_{2}(\mathrm{~L})\left(\mathrm{L}_{\mathrm{mono}}---\mathrm{H}_{2} \mathrm{O}\right)\left(\mathrm{OH}---\mathrm{H}_{2} \mathrm{O}\right)\right]^{-}+2\left[\mathrm{OH}---\mathrm{H}_{2} \mathrm{O}\right]^{-}+6 \mathrm{H}_{2} \mathrm{O}} \\
& {\left[\mathrm{UO}_{2}\left(\mathrm{OH}---\mathrm{H}_{2} \mathrm{O}\right)_{3}\left(\mathrm{H}_{2} \mathrm{O}---\left(\mathrm{H}_{2} \mathrm{O}\right)_{2}\right]^{-}+2\left[\mathrm{~L}---\left(\mathrm{H}_{2} \mathrm{O}\right)_{2}\right]^{-}=\right.} \\
& {\left[\mathrm{UO}_{2}(\mathrm{~L})_{2}\right]^{0}+3\left[\mathrm{OH}---\mathrm{H}_{2} \mathrm{O}\right]^{-}+7 \mathrm{H}_{2} \mathrm{O}}
\end{aligned}
$$




\section{Results and Discussion}

\subsection{Three-day batch experiments}

We first conducted control experiments with no DFOB added to reproduce the $U^{v /}$ precipitation observed in previous research at $\mathrm{pH} 11.5$ and ionic strength of $0.1 \mathrm{M} .{ }^{16,17}$ At equilibrium, we observed that only $4-5 \%$ of $U^{V /}$ was present in the solution after it was filtered through $0.2,0.45$ and $1 \mu \mathrm{m}$ nylon filter membranes. This means that $95-96 \%$ of $U^{v /}$ formed precipitates with diameter $\geq 1$ $\mu \mathrm{m}$, similar to previous research ${ }^{16,17}$ where $88-100 \%$ of $U^{\mathrm{Vl}}$ precipitated from solution. The reaction occurred rapidly with more than $90 \% \mathrm{U}^{\mathrm{V} /}$ precipitating from solution in approximately 8 hours.

When 4.2 $\mu \mathrm{M}$ DFOB was added to solution approximately $11-12 \%$ of $U^{\mathrm{vl}}$ passed through the filter membrane after the reaction reaches equilibrium, suppressing precipitate formation by $6 \%$ (Figure 2b). This indicates that siderophores will only have a small effect on aqueous $U^{\mathrm{VI}}$ chemistry when they are available in the concentration range expected in rocks $(<10 \mu \mathrm{M}) \cdot{ }^{19-22}$

Increasing DFOB concentration into the range found for siderophores in soils leads to significant suppression of $U^{\text {VI }}$ precipitate formation. When the DFOB concentration was increased to $42 \mu \mathrm{M}$ (1:1 ratio with $U^{\mathrm{VI}}$ ), 41-53\% of $U^{\mathrm{VI}}$ passed through the filter membranes (Figure 2c). When $130 \mu \mathrm{M}$ DFOB was present, $94-95 \%$ of $U^{V I}$ passed through the filter membranes indicating only $4-6 \%$ of $U^{V I}$ formed $\geq 1 \mu \mathrm{m}$ diameter precipitates (Figure $2 \mathrm{~d}$ ). Finally, $100 \%$ of $\mathrm{U}^{\mathrm{VI}}$ passed through the filter membranes when the DFOB concentration was increased to $420 \mu \mathrm{M}$ (Figure 2e), in the upper range of soil concentrations representative of the rhizosphere. Our previous research shows that in the absence of $\geq 0.2 \mu \mathrm{m}$ diameter precipitates, $\mathrm{U}^{\mathrm{Vl}}$ was highly mobile through quartz sand, ${ }^{17}$ suggesting DFOB could have a mobilising effect on $U^{\mathrm{v} !}$. 

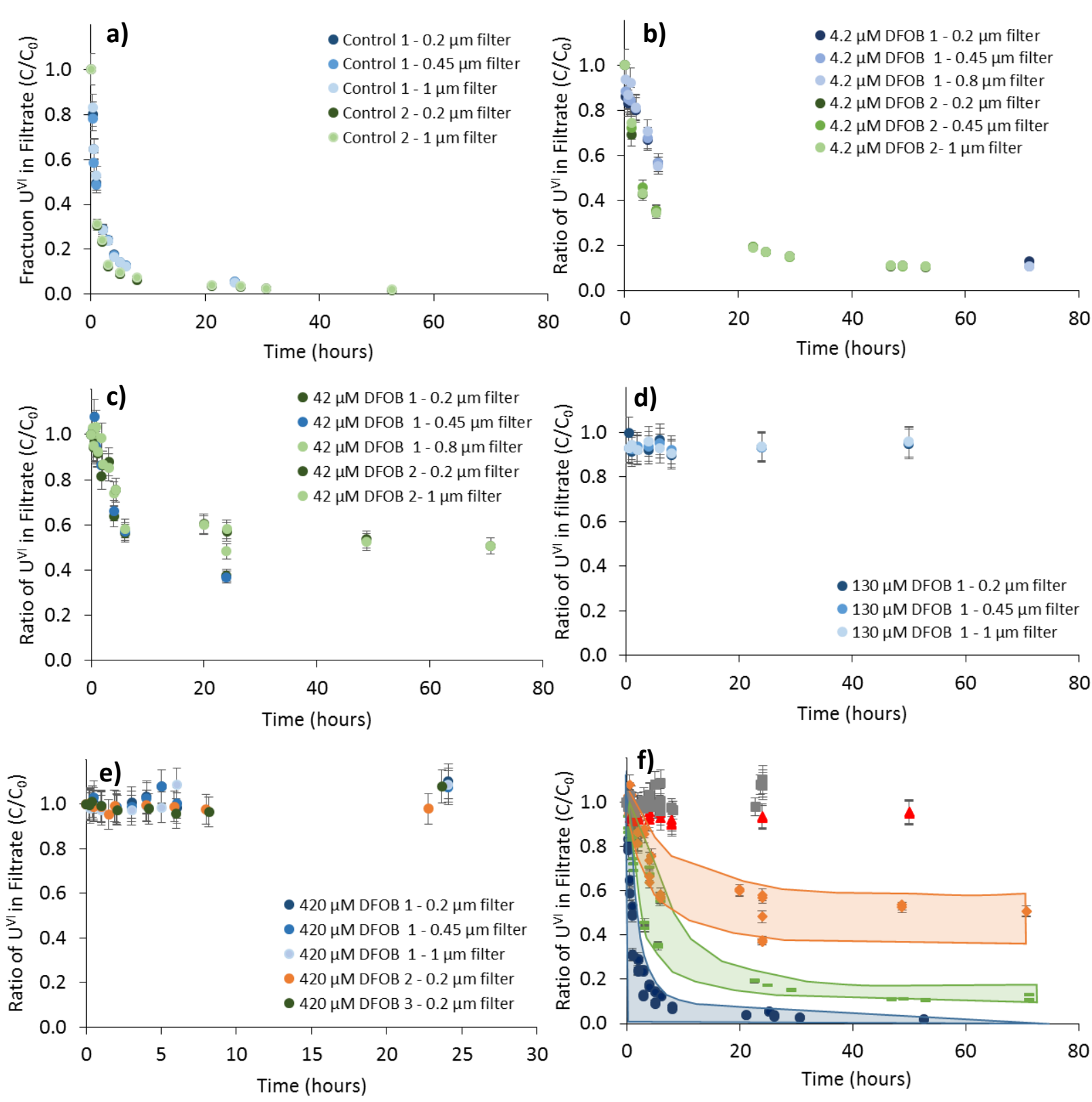

Figure 2. The effect of DFOB concentration on $U^{v /}$ precipitation over up to 3 days. a), b), c), d) and e) are the results from $0,4.2,42,130$, and $420 \mu \mathrm{M}$ [DFOB] respectively. The first, second and third experiments are given as blue, green and orange circles respectively. The darkest shade of colour represents the smallest filter $(0.45 \mu \mathrm{m})$ while the lightest shade represents the biggest filter $(1 \mu \mathrm{m})$ The data is overlain in f) where the blue circles, green bars, orange diamonds, red triangles and grey squares represent the $0,4.2,42,130$ and $420 \mu \mathrm{M}$ [DFOB] respectively. These are overlain with block colour as the second $4.2 \mu \mathrm{M}$ DFOB data overlaps with that of the $42 \mu \mathrm{M}$ DFOB data.

\subsubsection{Two-month batch experiments}

To understand whether the siderophore can impact $U^{v /}$ precipitation over longer time periods, the batch experiments were conducted over a two-month (56 day) time period. During these experiments $130 \mu \mathrm{M}$ DFOB was added to the $\mathrm{pH} 11.5,0.1 \mathrm{M} \mathrm{NaCl}$ solution before addition of $\mathrm{U}^{\mathrm{vl}}$. 
These $250 \mathrm{ml}$ samples were placed on a shaker tray at $25^{\circ} \mathrm{C}$ and $130 \mathrm{rpm}$ and $5 \mathrm{ml}$ samples were filtered through $0.2,0.45$ and $1 \mu \mathrm{m}$ filter membranes typically once a week. Dissolution experiments were also conducted where $250 \mathrm{ml}$ solutions containing $42 \mu \mathrm{M} \mathrm{U}^{\mathrm{vl}}$ and $0.1 \mathrm{M} \mathrm{NaCl}$ at pH 11.5 were placed on the shaker trays for 48 hours to allow $U^{v 1}$ to precipitate from solution. After 48 hours, 130 $\mu \mathrm{M}$ DFOB was added to the solution. Control experiments were conducted in the absence of $130 \mu \mathrm{M}$ DFOB to determine whether $U^{\text {VI }}$ precipitation remained stable over the two-month timeframe. The results are presented in Figure 3.

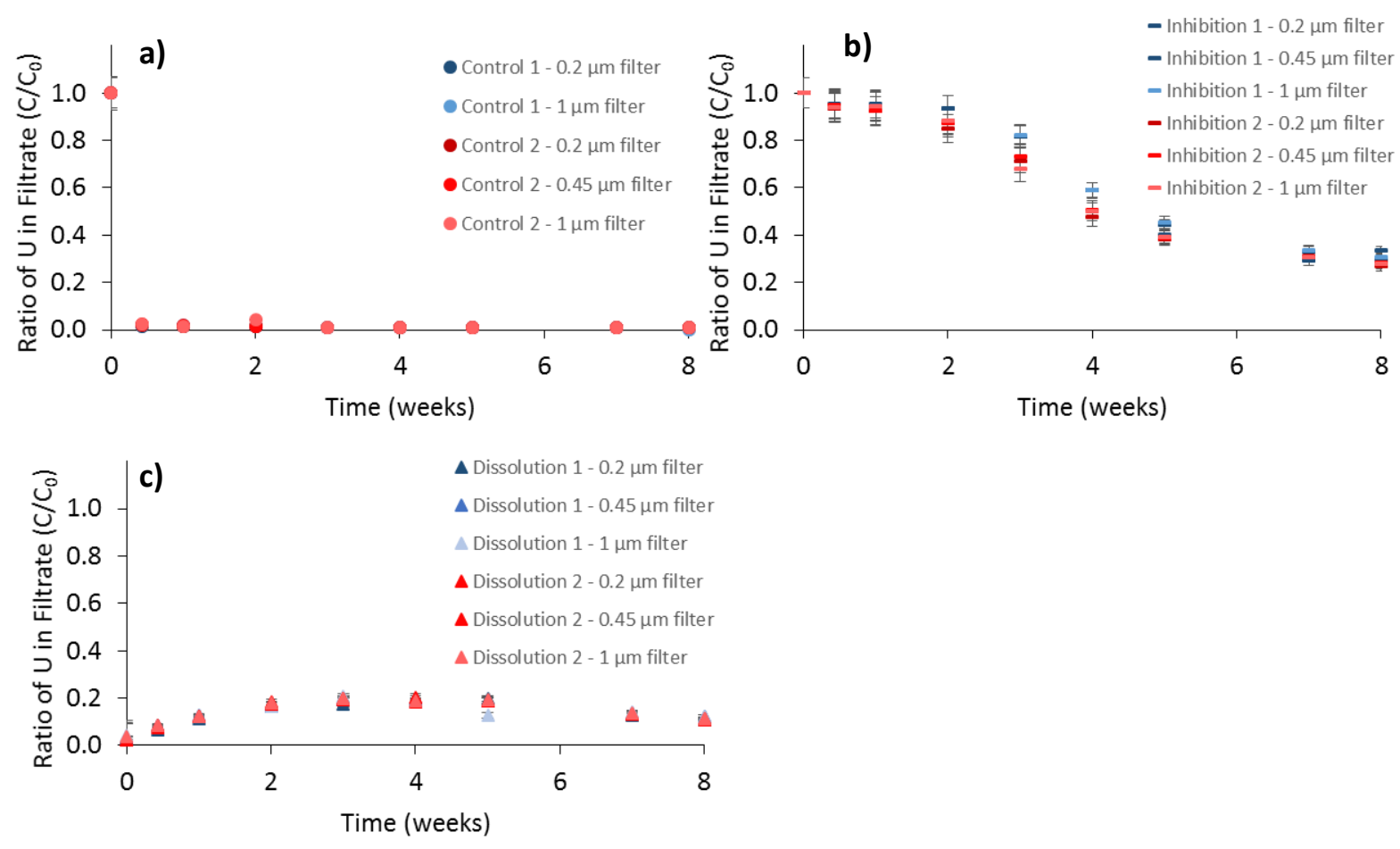

Figure 3. Results of batch experiments at $\mathrm{pH} 11.5$ containing $42 \mu \mathrm{M} \mathrm{U}^{\mathrm{V}}, 130 \mu \mathrm{M}$ DFOB and $0.1 \mathrm{M}$ $\mathrm{NaCl}$ which were conducted over a two-month time period. The results from the control experiment containing $42 \mu \mathrm{M} \mathrm{UVV}$ and $0 \mu \mathrm{M}$ DFOB are presented in part a), the results from the precipitation inhibition experiments are presented in part $b$ ) and the results from the dissolution experiments are presented in part c). The blue data points are the results from experiment 1 and the red points are results from experiment 2. Different shades represent the different filter sizes $(0.2,0.45$ and $1 \mu \mathrm{m}$ filter membrane pore size) where the darkest shade is $0.2 \mu \mathrm{m}$ and lightest shade is $1 \mu \mathrm{m}$.

The two control experiments show that up to $2 \%$ of $U^{\mathrm{Vl}}$ passed through the filter members over the two-month period, indicating virtually all $U^{\mathrm{VI}}$ had precipitated from solution (Figure 3a). This shows that in the absence of DFOB, the $U^{\mathrm{V}}$ precipitate remains stable in solution, and could be highly immobile in porous media, as observed in our previous research. ${ }^{17}$ 
During the inhibition experiments, approximately $6 \%$ of $U^{V /}$ was removed by all filter membranes sizes in the first week, suggesting that precipitate formation was inhibited by $94 \%$ (Figure 3b). This means DFOB could potentially significantly enhance the mobility of $U^{\mathrm{V} /}$ in porous media such as quartz sand. However, as time progressed, the amount of $U^{\mathrm{V}}$ removed by the filters increased. The change in $\mathrm{U}^{\mathrm{VI}}$ concentration in the filtrate was greatest between week 2 and 5 (day 14 and 35). On day $14,85-93 \%$ of $U^{\mathrm{VI}}$ passed through the filters while by day $35,40-45 \%$ passed through the filter membranes. After day 49 , equilibrium appeared to have been reached and $28-34 \% \mathrm{U}^{\mathrm{VI}}$ passed through the filter membranes. One mechanism responsible for increased $U^{v /}$ precipitation is the degradation of DFOB. ${ }^{48}$ The $U^{v 1}$ remaining in solution once ligand degradation had stabilised could be the result of UVI complexes forming with the degradation products of the siderophore.

The dissolution experiments indicate that $130 \mu \mathrm{M}$ DFOB solubilised approximately $20 \%$ of the $U^{\mathrm{VI}}$ precipitates (Figure 3c). This was stable for approximately five weeks before the particles started to re-aggregate or re-precipitate. Only $12 \%$ of $U^{\mathrm{VI}}$ remained in solution after two months. This demonstrates that DFOB dissolves $\mathrm{U}^{\mathrm{Vl}}$ after it has precipitated.

\subsection{Formation of $\mathrm{U}^{\mathrm{VI}}$ complexes with $\mathrm{DFOB}$ as a likely mechanism}

The experiments show that DFOB significantly reduces the amount of $U^{\mathrm{Vl}}$ precipitation at $\mathrm{pH}$ 11.5. One possible mechanism responsible for these observations is the formation of a $U^{\mathrm{VI}}-\mathrm{DFOB}$ complex as has been observed to form between $\mathrm{pH} 4-10 .{ }^{25}$ Multidentate ligands such as $\alpha$-isosaccharinic and D-gluconate complex with $\mathrm{U}^{\mathrm{VI}}$ at $\mathrm{pH} 12-13,,^{29-31}$ therefore it is possible for $\mathrm{U}^{\mathrm{VI}}$ to complex with negatively charged multidentate organic ligands at such a high pH. A key issue with characterising stability constants at high pH and ionic strengths is the alkaline errors in glass electrodes, and the formation of $\mathrm{U}^{\mathrm{VI}}$ precipitates hindering their experimental determination. ${ }^{29,32}$ The $\Delta_{r} G$ was calculated for the potential 1:1 and 1:2 $U^{v 1}$-hydroxamate complexes using Equations 1 to 7. The optimized $U^{v /}$ complexes are shown in Figure 4. The local binding modes of the hydroxamate functional group have been optimized as we expect most of the stability to be because 
of the electrostatic interactions between the functional group and $\mathrm{U}^{\mathrm{V}}$. We optimized complexes containing one or two hydroxamate ligands based on experimental observations for the functional group. ${ }^{49,50}$ Based on previous work, ${ }^{51}$ we assumed that hydroxamate will form a monodentate complex with $\mathrm{U}^{\mathrm{Vl}}$ via its deprotonated $\mathrm{O}$ atom, with the ligand oriented in the axial plane of $\mathrm{U}^{\mathrm{V}}$. The $\Delta_{r} G$ for the $U^{V I}$-hydroxamate complexes are provided in Table 1 . The results show that $\Delta_{r} G$ becomes more unfavourable as the number of displaced hydroxyl groups increases. This reflects the effort required by hydroxamate to break the co-ordination bond between the negatively charged $\mathrm{O}$ atom from the hydroxyl group and the positively charged $U^{v /}$ atom. The exceptions to this occur when the ligand forms a bidentate complex with $U^{v 1}$, suggesting an increased stability from the chelate effect outweighs the energy required to displace a further hydroxyl group. Consequently the most stable complex forms when a single hydroxamate complexes in a bidentate fashion with $U^{v 1}$ to form $\left[\mathrm{UO}_{2}(\mathrm{OH})_{2}(\mathrm{~L})\left(\mathrm{H}_{2} \mathrm{O}\right)_{2}\right]$. This is $11.6 \mathrm{~kJ} / \mathrm{mol}$ more negative than the next most stable complex $\left[\mathrm{UO}_{2}(\mathrm{OH})_{3}\left(\mathrm{Lmono}_{\mathrm{m}}\right)\left(\mathrm{H}_{2} \mathrm{O}\right)_{4}\right]^{2-}$. The remaining complexes have unfavourable $\Delta_{\mathrm{r}} \mathrm{G},>40 \mathrm{~kJ} / \mathrm{mol}$ more positive than that of $\left[\mathrm{UO}_{2}(\mathrm{OH})_{2}(\mathrm{~L})\left(\mathrm{H}_{2} \mathrm{O}\right)_{2}\right]^{\text {. }}$. 
a)

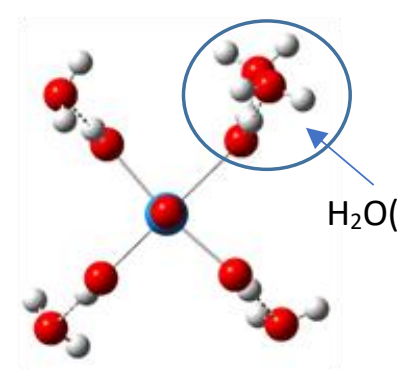

d)

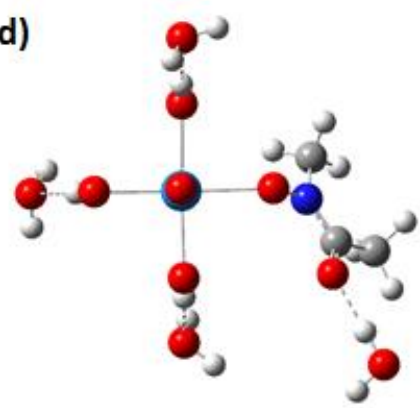

g)

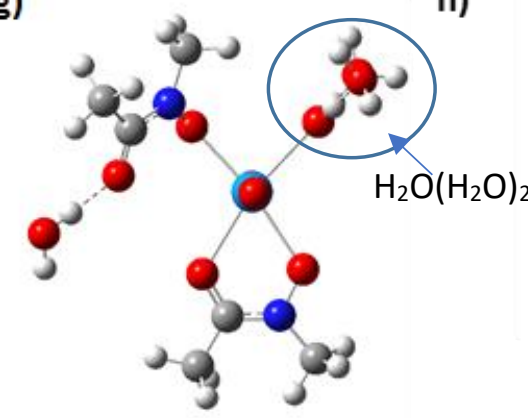

e) b)
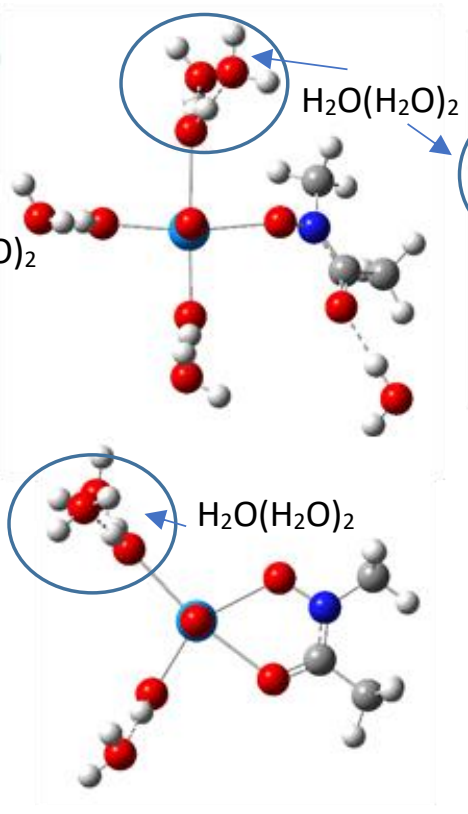

f)

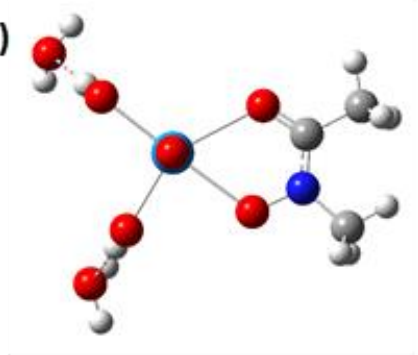

i)

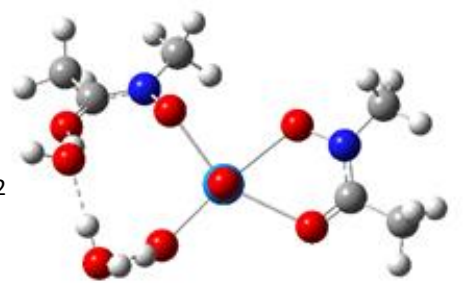

Figure 4. Structures of $U^{\mathrm{VI}}$ hydroxamate complexes using the mixed solvation model. a) is $\left[\mathrm{UO}_{2}(\mathrm{OH})_{3}\left(\mathrm{H}_{2} \mathrm{O}\right)\left(\mathrm{H}_{2} \mathrm{O}\right)_{5}\right]^{-}$b) and $\mathrm{c}$ ) are the $\mathrm{U}^{\mathrm{VI}}-\mathrm{L}$ complex in Equation 1 where hydroxamate is cis and trans to the $\mathrm{U}^{\mathrm{VI}}$ bound aqua ligand respectively. d) to i) are Equations 2 to 7 respectively. The white, grey, dark blue, grey, red and light blue atoms represent $\mathrm{H}, \mathrm{C}, \mathrm{N}, \mathrm{O}$ and $\mathrm{U}$ respectively.

To compare the computational results with the experimental results, the experimental stability was calculated and then converted to $\Delta_{r} G$ using Equation 8. In this equation $R, T$ and $\beta$ are the gas constant, absolute temperature, and stability constant, respectively.

$\Delta_{\mathrm{r}} \mathrm{G}=-2.30 \mathrm{RT} \log \beta_{11}$

The average $\log \beta_{11}$ calculated from the experiments is $-1.2 \pm 0.3$, and subsequently $\Delta_{r} G$ was calculated as $7 \pm 1 \mathrm{~kJ} / \mathrm{mol}$ respectively. This indicates a slightly unfavourable reaction. This is illustrated by the $42 \mu \mathrm{M}$ DFOB experiment where DFOB and $U^{\mathrm{VI}}$ are equimolar. If the reaction was 
favourable, virtually all $U^{\mathrm{VI}}$ should be complexed by the DFOB and no $U^{\mathrm{VI}}$ precipitates should have been observed. In comparison $\Delta_{\mathrm{r}} \mathrm{G}$ is +3 and $-9 \mathrm{~kJ} / \mathrm{mol}$ for $\left[\mathrm{UO}_{2}(\mathrm{OH})_{3}(\mathrm{~L}-\mathrm{mono})\right]^{2-}$ and $\left[\mathrm{UO}_{2}(\mathrm{OH})_{2}(\mathrm{~L})\right]$, which corresponds to -0.5 and $1.6 \log \beta$ units. This comparison suggests complexation of a hydroxamate functional group with $U^{v 1}$ is leading to the prevention of $U^{v 1}$ precipitation. However, to obtain accurate stability constants for $\mathrm{U}^{\mathrm{V} I}$-DFOB complexes in alkaline conditions using DFT, further study is required. This is because previous work has highlighted that the DFT methods need calibrating against experimental data to obtain accurate $\log \beta$ values. Such a calibration was not employed here due to the limited amount of data in these unique chemical conditions. The DFT calculations however strongly suggest that the formation of a $\mathrm{U}^{\mathrm{VI}}-\mathrm{DFOB}$ complex is a possible mechanism responsible for preventing $\mathrm{U}(\mathrm{VI})$ precipitation in $\mathrm{pH} 11.5,0.1 \mathrm{M} \mathrm{NaCl}$ solutions.

Table 1. The $\Delta_{\mathrm{r}} \mathrm{G}(\mathrm{kJ} / \mathrm{mol}), \Delta \Delta_{\mathrm{r}} \mathrm{G}(\mathrm{kJ} / \mathrm{mol})$ and number of displaced hydroxyl groups for each of the $U^{\mathrm{vl}}$ hydroxamate complexes generated from Equation 1 to 7 and shown in Figure 4.

\begin{tabular}{|l|l|l|l|l|l|}
\hline Species & Equation & Figure & $\begin{array}{l}\text { Number of } \\
\text { hydroxyl displaced }\end{array}$ & $\begin{array}{l}\boldsymbol{\Delta}_{\mathbf{r}} \mathbf{G} \\
(\mathbf{k j} / \mathbf{m o l})\end{array}$ & $\begin{array}{l}\boldsymbol{\Delta}_{\mathbf{r}} \mathbf{G} \\
(\mathbf{k j} / \mathbf{m o l})\end{array}$ \\
\hline $\mathrm{UO}_{2}(\mathrm{OH})_{2}(\mathrm{~L})$ & 4 & $4 \mathrm{f}$ & 1 & -9.0 & 0.0 \\
\hline $\mathrm{UO}_{2}(\mathrm{OH})_{3}\left(\mathrm{~L}_{\text {mono }}\right)$ & 1 & $4 \mathrm{~d}$ & 0 & 2.6 & 11.6 \\
\hline $\mathrm{UO}_{2}(\mathrm{OH})(\mathrm{L})\left(\mathrm{L}_{\text {mono }}\right)$ & 6 & $4 \mathrm{~h}$ & 2 & 32.1 & 41.1 \\
\hline $\mathrm{UO}_{2}(\mathrm{OH})_{2}\left(\mathrm{H}_{2} \mathrm{O}\right)\left(\mathrm{L}_{\text {mono }}\right)$-cis & 2 & $4 \mathrm{~b}$ & 1 & 36.9 & 45.9 \\
\hline $\mathrm{UO}_{2}(\mathrm{OH})_{2}\left(\mathrm{H}_{2} \mathrm{O}\right)\left(\mathrm{L}_{\text {mono }}\right)$-trans & 2 & $4 \mathrm{c}$ & 1 & 41.3 & 50.3 \\
\hline $\mathrm{UO}_{2}(\mathrm{OH})\left(\mathrm{H}_{2} \mathrm{O}\right)(\mathrm{L})$ & 3 & $4 \mathrm{e}$ & 2 & 50.6 & 59.6 \\
\hline $\left.\mathrm{UO}_{2}(\mathrm{~L})\right)_{2}$ & 7 & $4 \mathrm{i}$ & 3 & 63.0 & 72.0 \\
\hline $\mathrm{UO}_{2}(\mathrm{H} 2 \mathrm{O})(\mathrm{L})\left(\mathrm{L}_{\text {mono }}\right)$ & 5 & $4 \mathrm{~g}$ & 3 & 100.3 & 109.3 \\
\hline
\end{tabular}

\section{Conclusions}

The aim was to test the hypothesis that siderophore in alkaline and saline solutions inhibit $U^{v 1}$ precipitation and propose a possible mechanism responsible for this inhibition. This is important because siderophores occur naturally in the environment and potentially mobilise $U^{V 1}$ from a wide range of sources such as mine tailings, contaminated land and radioactive waste storage and disposal facilities. The results from a series of batch experiments show that DFOB can prevent 
almost $100 \% \mathrm{U}^{\mathrm{VI}}$ precipitation as $\geq 0.2 \mu \mathrm{m}$ precipitates for two weeks, and dissolve up to $20 \% \mathrm{U}^{\mathrm{VI}}$ between two and five weeks, when $130 \mu \mathrm{M}$ DFOB is initially present. We have previously observed that when $U^{v 1}$ is highly mobile in porous media when $U^{v 1}$ not present as $\geq 0.2 \mu \mathrm{m}$ precipitates. As $U^{v 1}$ precipitation is prevented by addition of DFOB, and $U^{v 1}$ dissolution is enhanced, DFOB could have a significant impact on the mobility of $\mathrm{U}^{\mathrm{Vl}}$ in soil environments where siderophore concentrations can reach $1 \mathrm{mM}$. Further research is now required to determine the effects of different mineralogies, organic matter and competitive cations on $\mathrm{U}^{\mathrm{VI}}$ mobility in the presence of DFOB.

The formation of a $\mathrm{U}^{\mathrm{VI}}$-DFOB siderophore complex is a likely mechanism based on electron structure calculations. DFT was employed to calculate the $\Delta_{r} G$, and subsequently $\log \beta$ of $1: 1$ and $1: 2 U^{\mathrm{vI}}$ hydroxamate complexes. The proposed local binding mode is for one hydroxamate group to displace the $\mathrm{U}^{\mathrm{Vl}}$ bound water molecule, forming a chelate, $\left[\mathrm{UO}_{2}(\mathrm{OH})_{2}(\mathrm{~L})\right]^{\text {. }}$.

\section{Acknowledgements}

We acknowledge the Natural Environment Research Council (NERC), Radioactive Waste Management Limited (RWM), Environment Agency (EA) and Science and Technology Facilities Council (STFC) for the funding received for this project through the Hydroframe consortium, part of the Radioactivity and the Environment (RATE) programme (NE/ L000660/1). We thank Imperial HPC for access to the cx1 supercomputer. We thank Dr Alexandra Simperler for her advice during the research.

\section{References}

1. DECC Implementing geological disposal: A framework for the long term management of higher activity radioactive waste; Department of Energy and Climate Change: London, SW1A 2AW, 2014; p 55.

2. SG Implementation strategy for Scotland's policy on higher activity radioactive waste; Scottish Government: Edinburgh, EH1 3DG, 2016; $p 46$.

3. LLWR Engineering Design; Cumbria, CA19 1XH, 2011; 115.

4. NDA Geological Disposal Near-field Evolution Status Report; Oxfordshire OX11 ORH, 2010; p 152. 
5. Stockdale, A.; Bryan, N. D., The influence of natural organic matter on radionuclide mobility under conditions relevant to cementitious disposal of radioactive wastes: A review of direct evidence. Earth-Science Reviews 2013, 121, 1-17.

6. Gephart, R. E., A short history of waste management at the Hanford Site. Physics and Chemistry of the Earth 2010, 35 (6-8), 298-306.

7. Szecsody, J. E.; Truex, M. J.; Qafoku, N. P.; Wellman, D. M.; Resch, T.; Zhong, L. R., Influence of acidic and alkaline waste solution properties on uranium migration in subsurface sediments. Journal of Contaminant Hydrology 2013, 151, 155-175.

8. Kaplan, D. I.; Gervais, T. L.; Krupka, K. M., Uranium(VI) sorption to sediments under high pH and ionic strength conditions. Radiochimica Acta 1998, 80 (4), 201-211.

9. Parry, S. A.; O'Brien, L.; Fellerman, A. S.; Eaves, C. J.; Milestone, N. B.; Bryan, N. D.; Livens, F. R., Plutonium behaviour in nuclear fuel storage pond effluents. Energy \& Environmental Science 2011, 4 (4), 1457-1464.

10. Bondici, V. F.; Lawrence, J. R.; Khan, N. H.; Hill, J. E.; Yergeau, E.; Wolfaardt, G. M.; Warner, J.; Korber, D. R., Microbial communities in low permeability, high pH uranium mine tailings: characterization and potential effects. Journal of Applied Microbiology 2013, 114 (6), 1671-1686.

11. Alexander, W. R.; Dayal, R.; Eagleson, K.; Eikenberg, J.; Hamilton, E.; Linklater, C. M.; McKinley, I. G.; Tweed, C. J., A natural analog of high pH cement pore waters from the Maqarin are of Northern Jordan .2. Results of predictive geochemical calculations. Journal of Geochemical Exploration 1992, 46 (1), 133-146.

12. Khoury, H. N.; Salameh, E.; Clark, I. D.; Fritz, P.; Bajjali, W.; Milodowski, A. E.; Cave, M. R.; Alexander, W. R., A natural analog of high $\mathrm{pH}$ cement pore waters from the Maqarin area of Northern Jordan .1. Introduction to the site. Journal of Geochemical Exploration 1992, 46 (1), 117132.

13. Rizoulis, A.; Milodowski, A. E.; Morris, K.; Lloyd, J. R., Bacterial diversity in the hyperalkaline Allas Springs (Cyprus), a natural analogue for cementitious radioactive waste Repository. Geomicrobiology Journal 2016, 33 (2), 73-84.

14. Fan, Q. H.; Hao, L. M.; Wang, C. L.; Zheng, Z.; Liu, C. L.; Wu, W. S., The adsorption behavior of $\mathrm{U}(\mathrm{VI})$ on granite. Environmental Science-Processes \& Impacts 2014, 16 (3), 534-541.

15. Zhang, Y. Y.; Zhao, H. G.; Fan, Q. H.; Zheng, X. B.; Li, P.; Liu, S. P.; Wu, W. S., Sorption of $\mathrm{U}(\mathrm{VI})$ onto a decarbonated calcareous soil. Journal of Radioanalytical and Nuclear Chemistry 2011, 288 (2), 395-404.

16. Kenney, J. P. L.; M.E., K.; Cuadros, J.; Weiss, D. J., A conceptual model to predict uranium removal from aqueous solutions in water-rock systems associated with low- and intermediate-level radioactive waste disposal. RSC Advances 2017, 7, 7876-7884.

17. Kirby, M. E.; Watson, J. S.; Najorka, J.; Kenney, J. P. L.; Krevor, S.; Weiss, D. J., Experimental study of $\mathrm{pH}$ effect on uranium (UVI) particle formation and transport through quartz sand in alkaline $0.1 \mathrm{M}$ sodium chloride solutions. Colloids and Surfaces A: Physicochemical and Engineering Aspects 2020, 592, 124375.

18. Hider, R. C.; Kong, X. L., Chemistry and biology of siderophores. Natural Product Reports 2010, 27 (5), 637-657.

19. Romheld, V., The role of phytosiderophores in acquisition of iron and other micronutrients in gramineous species - An ecological approach. Plant and Soil 1991, 130 (1-2), 127-134.

20. Kraemer, D.; Kopf, S.; Bau, M., Oxidative mobilization of cerium and uranium and enhanced release of "immobile" high field strength elements from igneous rocks in the presence of the biogenic siderophore desferrioxamine B. Geochimica Et Cosmochimica Acta 2015, 165, 263-279.

21. Kraemer, S. M., Iron oxide dissolution and solubility in the presence of siderophores. Aquatic Sciences 2004, 66 (1), 3-18.

22. Powell, P. E.; Cline, G. R.; Reid, C. P. P.; Szaniszlo, P. J., Occurrence of hydroxomate siderophore iron chelators in soils. Nature 1980, 287 (5785), 833-834. 
23. Kiss, T.; Farkas, E., Metal-binding ability of desferrioxamine B. Journal of Inclusion Phenomena and Molecular Recognition in Chemistry 1998, 32 (2-3), 385-403.

24. Frazier, S. W.; Kretzschmar, R.; Kraemer, S. M., Bacterial siderophores promote dissolution of UO2 under reducing conditions. Environmental Science \& Technology 2005, 39 (15), 5709-5715. 25. Mullen, L.; Gong, C.; Czerwinski, K., Complexation of uranium(VI) with the siderophore desferrioxamine B. Journal of Radioanalytical and Nuclear Chemistry 2007, 273 (3), 683-688. 26. Anderson, C.; Johnsson, A.; Moll, H.; Pedersen, K., Radionuclide geomicrobiology of the deep biosphere. Geomicrobiology Journal 2011, 28 (5-6), 540-561.

27. Warwick, P.; Evans, N.; Hall, T.; Vines, S., Stability constants of uranium(IV)-alphaisosaccharinic acid and gluconic acid complexes. Radiochimica Acta 2004, 92 (12), 897-902. 28. Gaona, X.; Montoya, V.; Colas, E.; Grive, M.; Duro, L., Review of the complexation of tetravalent actinides by ISA and gluconate under alkaline to hyperalkaline conditions. Journal of Contaminant Hydrology 2008, 102 (3-4), 217-227.

29. Colas, E.; Grive, M.; Rojo, I., Complexation of uranium(VI) by bluconate in alkaline solutions. Journal of Solution Chemistry 2013, 42 (7), 1545-1557.

30. Warwick, P.; Evans, N.; Vines, S., Studies on some divalent metal alpha-isosaccharinic acid complexes. Radiochimica Acta 2006, 94 (6-7), 363-368.

31. Sawyer, D. T.; Kula, R. J., Uranium(VI) gluconate complexes. Inorganic Chemistry 1962, 1 (2), 303-309.

32. Harris, D. C., Quantitative chemical analysis. 8th ed., International ed. ed.; New York: W. H. Freeman: New York, 2010.

33. Frisch, M. J.; Trucks, G. W.; Schlegel, H. B.; Scuseria, G. E.; Robb, M. A.; Cheeseman, J. R.; Scalmani, G.; Barone, V.; Petersson, G. A.; Nakatsuji, H.; al., e. Gaussian 16 Rev. a.01, Wallingford, CT, 2016.

34. Dennington, R.; Keith, T. A.; Millam, J. M. GaussView, Version 6, Semichem Inc.: Shawnee Mission, KS, 2016.

35. McQuarrie, D. A., Physical chemistry : a molecular approach. University Science Books: Sausalito, 1997.

36. Kirby, M. E.; Simperler, A.; Krevor, S.; Weiss, D. J.; Sonnenberg, J. L., Computational tools for calculating log beta values of geochemically relevant uranium organometallic complexes. Journal of Physical Chemistry A 2018, 122 (40), 8007-8019.

37. Becke, A. D., Density-Functiona; Thermochemistry .3. The role of exact exchange. Journal of Chemical Physics 1993, 98 (7), 5648-5652.

38. Lee, C.; Yang, W.; Parr, R. G., Development of the Colle-Salvetti correlation-energy formula into a functional of the electron density. Phys. Rev. B: Condens. Matter 1988, 37 (2), 785-789.

39. Stephens, P. J.; Devlin, F. J.; Chabalowski, C. F.; Frisch, M. J., Ab-initio calculation of vibrational absorption and circular-dichroism spectra using density-functional force-fields. Journal of Physical Chemistry 1994, 98 (45), 11623-11627.

40. Woon, D. E.; Dunning, T. H., Gaussian-basis sets for use in correlated molecular calculations .3. The atoms aluminum through argon. Journal of Chemical Physics 1993, 98 (2), 1358-1371.

41. Kendall, R. A.; Dunning, T. H.; Harrison, R. J., Electron-affinities of the $1^{\text {st }}$-row atoms revisited - systematic basis-sets and wave-functions. Journal of Chemical Physics 1992, 96 (9), 6796-6806.

42. Dunning, T. H., Gaussian-basis sets for use in correlated molecular calculations .1. The atoms boron through neon and hydrogen. Journal of Chemical Physics 1989, 90 (2), 1007-1023.

43. Dolg, M.; Cao, X. Y., Accurate relativistic small-core pseudopotentials for actinides. Energy adjustment for rranium and first applications to uranium hydride. Journal of Physical Chemistry $A$ 2009, 113 (45), 12573-12581.

44. Tomasi, J.; Mennucci, B.; Cances, E., The IEF version of the PCM solvation method: an overview of a new method addressed to study molecular solutes at the $\mathrm{QM}$ ab initio level. Journal of Molecular Structure-Theochem 1999, 464 (1-3), 211-226. 
45. Ingram, K. I. M.; Haller, L. J. L.; Kaltsoyannis, N., Density functional theory investigation of the geometric and electronic structures of $\left[\mathrm{UO}_{2}\left(\mathrm{H}_{2} \mathrm{O}\right)_{m}(\mathrm{OH})_{n}\right]^{(2-n)}(n+m=5)$. Dalton Transactions 2006, (20), 2403-2414.

46. Gutowski, K. E.; Dixon, D. A., Predicting the energy of the water exchange reaction and free energy of solvation for the uranyl ion in aqueous solution. Journal of Physical Chemistry A 2006, 110 (28), 8840-8856.

47. Kelly, C. P.; Cramer, C. J.; Truhlar, D. G., Adding explicit solvent molecules to continuum solvent calculations for the calculation of aqueous acid dissociation constants. Journal of Physical Chemistry A 2006, 110 (7), 2493-2499.

48. Sigma-Aldrich, Desferrioxamine Mesylate Material Data Safety Sheet. Sigma-Aldrich: Saint Louis, MO 63103 USA, 2020.

49. Chung, D. Y.; Choi, E. K.; Lee, E. H.; Kim, K. W., Complexation of U(VI), Ce(III) and Nd(III) with acetohydroxamic acid in perchlorate aqueous solution. Journal of Radioanalytical and Nuclear Chemistry 2011, 289 (2), 315-319.

50. Sornosa-Ten, A.; Jewula, P.; Fodor, T.; Brandes, S.; Sladkov, V.; Rousselin, Y.; Stern, C.; Chambron, J. C.; Meyer, M., Effects of preorganization in the chelation of $\mathrm{UO}_{2}{ }^{2+}$ by hydroxamate ligands: cyclic PIPO- vs. linear NMA. New Journal of Chemistry 2018, 42 (10), 7765-7779.

51. Kirby, M. E.; L., S. J.; A., S.; J., W. D., Stability series for the complexation of six key siderophore functional groups with uranyl using density functional theory. The Journal of Physical Chemistry A 2020, 124 (12), 2460-2472. 